https://doi.org/10.52444/nr.2.1.4

Primljeno: 4. ožujka 2021.

Prihvaćeno: 3. lipnja 2021.

Pregledni rad

\title{
KRIVNJA I OPROST
}

\section{SAŽETAK}

dr. sc. Irena HABAZIN

Škola za medicinske sestre Vinogradska

Vinogradska cesta 29, Zagreb

ihabazin@gmail.com

\begin{abstract}
Krivnja s aspekta tragične trijade logoterapijskog pristupa Viktora Frankla predstavlja životno iskustvo zajedničko svim ljudima. Uvažavajući dostojanstvo osobe, krivnju se ne može promatrati isključujući slobodu i odgovornost svake pojedine osobe koja odabire svoja ponašanja i za koja ne može biti oslobođena odgovornosti. Može se reći da gotovo ne postoji osoba koja nije počinila nešto što si kasnije nije mogla oprostiti, isto tako nema osobe koja nije doživjela počinjenu nepravdu. Bilo da je osoba „počinitelj“ ili „žrtva“, kako bi se poništile brojne negativne posljedice osjećaja krivnje potrebno je oprostiti, pri čemu je najteže oprostiti samome sebi. Svrha rada je potaknuti svaku osobu, a posebice one uključene u pomažuće profesije, preispitati ulogu krivnje u svom životu i na razmišljanje o potrebi opraštanja kao preduvjeta osobnog i profesionalnog prosperiteta. U radu su objašnjeni konstrukti krivnje i oprosta s posebnim naglaskom na logoterapijski pristup.
\end{abstract}

Ključne riječi: krivnja, oprost, logoterapija.

\section{UVOD}

Od svih zala najgora je krivnja. (Johann Christoph Friedrich von Schiller)

Malo koja osoba nije osjetila krivnju zbog nečega što je izrekla ili ne izrekla, odnosno počinila ili ne počinila. Isto tako, rijetko tko nije osjetio nepravdu koju mu je netko nanio svojim riječima ili postupcima. Krivnja, uz patnju i smrt čini tragični trijas koji ni jedna osoba tijekom života neće biti pošteđena (Pahljina, 2020). Kada je riječ o krivnji, centralno mjesto zauzima savjest koja vrlo tihim glasom govori osobi o najsmislenijem odabiru postupanja u određenoj situaciji te koji ona odabire po svojoj slobodnoj volji i time preuzima odgovornost za (ne)učinjeno. Prema tome, krivnja uključuje: a) odluku donesenu na temelju slobodne volje i b) jasno prepoznavanje smisla (Lukas, 2021: 113). Pahljina (2020) govori od dva temeljna oblika krivnje koja su praćena osjećajem krivnje ili doživljajem nanesene nepravde. Kako bi se poništile negativne posljedice vezane uz krivnju, svaka osoba može preuzeti odgovornost savladavanja krivnje (Frankl, 2010: 135) i to kroz oprost. Bilo da je riječ o opraštanju sebi ili nekome zbog nepravednog postupanja, osoba će pokazati sposobnost 
nadrastanja same sebe $i$ time unijeti pozitivne promjene u svoj život.

\section{KRIVNJA}

Osjećaj krivnje predstavlja vrlo složenu emociju koja je vezan uz socijalne odnose i određen je osobnošću neke osobe, njezinim odgojem i iskustvima tijekom života, a ponajviše o njezinim stavovima, sustavom vrijednosti i moralnim normama. Lukas naglašava važnost ,individualnog korištenja i upravljanja vlastitim karakternim crtama“ (2021: 111). Stoga možemo očekivati da je taj osjećaj različit kod svake osobe i da se razlikuje s obzirom na različita kulturalna okruženja.

Hrvatska enciklopedija (2021) donosi definiciju krivnje: ,subjektivni odnos osobe prema vlastitomu činu (činjenju ili propuštanju činjenja) i njegovoj posljedici, koji se ocjenjuju kao zli (štetni, zabranjeni) sa stajališta pravnoga poretka, morala ili vjere".

Prema Psihologijskom rječniku (Petz, 1992) krivnja predstavlja: „neprijatan emocionalni doživljaj koji prati saznanje o kršenju ili narušavanju moralnih normi i pravila ponašanja“.

Logoterapijski pristup govori da je krivnja specifično ljudski fenomen povezan $\mathrm{S}$ duhovnom slobodom, odgovornošću i savješću pojedine osobe. Prema tome krivnja je posljedica izbora pogrešnog postupanja. Pahljina (2020) krivnju opisuje kao pogrešan model ponašanja, pri čemu razlikuje dva oblika krivnje: a) osoba, napravivši loš odabir, nekome je nešto skrivila i posljedično tomu osjeća grižnju savjesti; b) netko drugi je napravio loš odabir te se osoba osjeća kao žrtva kojoj je nanesena nepravda. Pilja (2009) razlikuje sram koji vezuje uz okrivljavanje samog sebe, svojeg karaktera, od krivnje, koju vezuje uz ponašanje. Nadalje, govoreći o „kršćanskoj definiciji“ razlikuje objektivnu krivnju (osjećaj opće grešnosti) i subjektivnu (osjećaj osobne krivnje) krivnju pred Bogom. S obzirom na subjektivni osjećaj krivnje, razlikuje zdravu krivnju, koja pomaže u ponašanju sukladno važećim normama, od nezdrave krivnje, koja je nametnuta i prati je osjećaj srama (samokažnjavanje, samoodobacivanje).

U literaturi se susrećemo i s podjelom na lažnu i stvarnu krivnju (Jurković, 2020). Lažna krivnja predstavlja nametnuti osjećaja odgovornosti za nešto za što ne postoji racionalna odgovornost. Ona može biti posljedica djetinjstva obilježena strogim kažnjavanjem i zlostavljanjem ili preživljavanja velikih nesreća i katastrofa praćenih gubitkom ljudskih života. Osoba uz krivnju osjeća sram, ima negativnu sliku o sebi i svojim sposobnostima, okrivljuje 
sebe i preuzima krivnju za postupke za koje nije odgovorna. Stvarna krivnja posljedica je činjena na štetu nekoga ili nečega. Ishodište joj je u savjesti koja govori određenoj osobi da njezin postupak nije bio dobar i da bi trebala slijediti kazna od koje želi pobjeći, a za koju osjeća da bi bila zaslužena. Osim individualne krivnje, važno je spomenuti i kolektivnu krivnju (Penić, Čorkalo Biruški, 2008), koja proizlazi iz osjećaja pripadanja različitim socijalnim grupama (socijalni identitet). Riječ je krivnji temeljenoj na pripadanju određenoj grupi i razlikuju se dva oblika: a) pripisivanje kolektivne krivnje - vlastita grupa je bila izložena štetnom postupanju druge grupe, b) prihvaćanje kolektivne krivnje - vlastita je grupa štetno postupala s drugom grupom. Pojedini pripadnik grupe doživljava kolektivnu krivnju čak i ako on sam nije odgovoran za štetno postupanje grupe. Frankl (2010: 135) naglašava da je nepravedno određenoj osobi pripisati odgovornost za ponašanje članova grupe.

Tema krivnje uglavnom se izbjegava i većina ljudi nerado razgovora o njoj, posebice ako je riječ o krivnji nanesenoj nekome drugome. Lukas (2021: 105) navodi da jedan od razloga izbjegavanja teme krivnje leži u činjenici da je teško samom sebi priznati vlastite promašaje $i$ propuste. Ipak si većina ljudi rijetko postavlja pitanje: „ک̌ to sam mogao/la bolje učiniti i što bih mogao/la bolje učiniti?"“ Monbourquette (1997: 123) smatra da u postupku opraštanja temeljno mjesto zauzima oproštenje samomu sebi. Tu je važno podsjetiti se da osjećaj krivnje može biti opravdan ili neopravdan, odnosno trebalo bi razlikovati racionalni osjećaj od iracionalnog. Lukas (2021: 108) razlikuje osjećaj krivnje koji proizlazi iz „savjesne svijesti o odgovornosti“ i i rezultira pogrešnom odlukom, od ,zablude pretjerano osjetljive psihe“, koja sve loše dovodi u vezu sa samim sobom i svojim nedostacima. Osim toga, upozorava da osjećaj krivnje može biti i simptom duševne bolesti kod depresivnih i opsesivnokompulzivnih pacijenata.

Brojni pripadnici tzv. pomažućih profesija svakodnevno svjedoče o nepovoljnom utjecaju krivnje na duševno zdravlje pojedinaca. Krivnja se, također smatra značajnim ishodištem mnogih problema $\mathrm{u}$ međuljudskim odnosima $u$ privatnom $\mathrm{i}$ profesionalnom kontekstu. Osoba koja je doživjela krivnju teško se odmiče od toga osjećaja i ponašanja u skladu s tim. Nju neprestano prate osjećaj krivnje, grižnja savjesti ili nanesena joj nepravda.

Frankl (2010: 125, 126) smatra da svaka osoba, unatoč tragičnim aspektima života, ima sposobnost preokrenuti ih $\mathrm{u}$ nešto pozitivno i konstruktivno. Najvažnije je da se iz svake situacije izvuče ono najbolje. 
Riječ je o „tragičnom optimizmu“ koji upućuje na činjenicu ,da se iz osjećaja krivnje stvori prilika da se pojedinac promijeni nabolje“. Pahljina (2020) daje preporuku da se svaka osoba zapita na čemu može biti zahvalna i da pokuša odgovoriti na pitanje: „Koji smisao konkretna krivnja ima u mom životu?““

\section{OPROST}

Ako ste povrijedili, tražite oproštenje, ako ste povrijeđeni, oprostite. (Etiopska poslovica)

U posljednje vrijeme može se svjedočiti traženju oproštenja za nanesenu krivnju (nepravdu) pojedinim osobama i skupinama na svim razinama društva.

Traženju oproštaja ili pokušaju popravljanja štete prethodi priznavanje vlastite krivnje ili pogreške i preuzimanje odgovornosti za štetno postupanje. Monbourquette i Aspremont (2014: 51-59) navode da uspješno priznavanje pogreške uključuje i prepoznavanje vlastitih emocionalnih stanja: osjećaj srama, razlikovanje zdravog od nezdravog osjećaja krivnje, grižnju savjesti, žaljenje i u konačnici istinsko kajanje.

Krivnju kao posljedicu pogrešnog postupanja moguće je popraviti na više načina. Polazeći od duhovne dimenzije u kojoj se nalazi savjest, svaka osoba ima slobodnu volju da napravi dobar odabir, onaj koji je najsmisleniji za određenu situaciju (Pahljina, 2020). Načini popravljanja pogrešnog postupanja:

- priznati pogrešku i zatražiti oproštenje izravno od povrijeđene osobe; to je priznavanje krivnje i kajanje za štetno postupanje. Pritom treba biti autentičan, direktan, jasan, a isprika treba biti dobro formulirana i po mogućnosti afirmativna (Monbourquette, Aspremont, 2014, 96-107). Nikako nije dobro racionalizirati i psihologizirati jer na taj način dolazi do zamjene uloga: osoba koja se ispričava za štetno postupanje prema nekome traži da ju taj netko razumije i opravda njezin postupak;

- u slučaju nedostupnosti osobe, tj. ako ona ne želi razgovarati ili joj se zbog daljine nije moguće direktno ispričati, krivnju je moguće popraviti činjenjem dobrog djela koje se inače ne bi činilo i to u mjeri u kojoj je napravljeno ono loše;

- ako je osoba kojoj je nanesena krivnja umrla, moguće je u logoterapiji uz vođenje logoterapeuta provesti tzv. „Zamišljeni dijalog $\mathrm{s}$ udaljenim sugovornikom“.

Lukas (2000, 2013: 31-35) navodi da je moguće popraviti krivnju mijenjanjem unutarnjeg stava, a što podrazumijeva promjenu u duhovnoj dimenziji. Osoba se 
nakon dugotrajnog procesa mijenja $\mathrm{i}$ to $\mathrm{u}$ bolju osobu koja donosi odluku da u slučaju kada bi se vratila u istu situaciju ili kada bi se ponovila slična, ne bi više štetno postupala. Slično tomu i osoba na smrtnoj postelji može se istinski pokajati za svoje prijašnje štetno postupanje. Kajanje briše krivnju koju nije moguće poništiti, točnije nemoguće je poništiti učinjenu krivnju, ali osoba, zahvaljujući sposobnosti spoznavanja dobra i(zla, donosi unutarnji stav o nemogućnosti ponavljanja štetnog postupka. Ako se kajanje provede svjesno, iskreno i pošteno, onda se osoba mijenja u svojoj nutrini i time postaje nova i bolja osoba.

Smatra se da je krivnja odgovorna za brojne probleme, ponajprije u području duševnog zdravlja. Lukas (2001: 47-52) razmatra posljedice brojnih pogrešnih roditeljskih postupanja, navodi da je devetero od njezinih deset pacijenata kritiziralo svoje roditelje. Povezujući iskustva ostalih psihoterapeuta koji su zaključili da su se zbog pogrešnih odgojnih postupanja roditelja brojna djeca duševno razboljela, nudi diferencirani zaključak. Polazeći od logoterapijskog pristupa Dekalogu (biblijskih Deset Božjih zapovijedi), četvrtu zapovijed! („,Poštuj oca i majku da dugo živiš i dobro ti bude na zemlji!“) smatra važnom za razvoj duševne stabilnosti i osobne zrelosti. Moguće je ustvrditi da su osobe oboljele od duševne bolesti najčešće one koje odbacuju svoje roditelje kojima ne mogu oprostiti pogrešno postupanje i krive ih za svoje poteškoće, te zaključiti da su to osobe koje ne „poštuju“ svoje roditelje. Dodatno pojašnjava značenje ,poštovanja“: a) ako roditelj poštuje svoje dijete, odgaja ga s ljubavlju sukladno njegovim potrebama $\mathrm{s}$ ciljem razvoja njegove otpornosti, b) ako odraslo dijete poštuje roditelja, ne ignorira ga i ne sukobljava se s njim, posjećuje ga i po potrebi podupire, pomažući mu u savladavanju kriza „praznog ognjišta“, umirovljenja i staračke nemoći. Lukas postavlja pitanje: Kako je moguće spojiti činjenicu da djeca koja „poštuju“ svoje roditelje, dakle koja iz vole i paze na njih, dakle trebali bi se osjećaju dobro i zdravo, dok navedeni rezultati psihoterapijske prakse to ne pokazuju.

Ako je osoba bila povrijeđena, ključno je za njezin oporavak i izlječenje opraštanje onome tko ju je povrijedio (Jurković, 2020). Ona ne oprašta zbog drugih, da bi pomogla drugome, oprašta radi same sebe i pozitivnih učinaka u području svojeg tjelesnog, mentalnog, emocionalnog i duhovnog zdravlja (Tutu i Tutu, 2017).

Opraštanje se nikako ne smije poistovjetiti s zaboravljanjem, koje zapravo onemogućuje istinsko oproštenje. Smedes (1997: 52-59) navodi da se najčešće zaboravljaju beznačajne povrede $i$ one izrazito 
traumatične s kojima se osoba ne može nositi. Posebice je teško oprostiti osobama od kojih se ne može očekivati kajanje, kao što su: nepoznate osobe koje su uslijed nepogodnih životnih okolnosti ostavile bolna sjećanja, izrazito zle osobe, osobe kojima je svejedno za nanesenu bol, osobe koje su umrle. Također je važno naglasiti da oproštenje ne predstavlja slabost osobe koja oprašta. Upravo suprotno! Jer da se oprostilo potrebna je velika hrabrost i snaga (Tutu, Tutu, 2017: 41-48).

Monbourquette (1997: 24-37) navodi pogrešna shvaćanja opraštanja koja naziva „lažnim idejama o opraštanju“. Tu su: a) oprostiti ne znači zaboraviti; b) oprostiti ne znači nijekati (obrambena reakcija); c) opraštanje traži više no što je voljan čin, odnosno, opraštanje se ne može narediti, ono je ili slobodno ili ne postoji; d) opraštanje ne znači biti kao prije uvrede, dakle, ono nije istoznačno s pomirenjem; e) opraštanje ne traži da se odreknemo svojih prava (to bi značilo miješati pojmove opraštanje i pravednost); f) oprostiti drugomu ne znači opravdati ga; g) opraštanje nije dokazivanje moralne nadmoći (dokazivanje moći nasuprot očitovanju unutarnje snage u prihvaćanju vlastite ranjivosti); h) opraštanje nije prebacivanje odgovornosti na Boga (opraštanje uključuje i božanski i ljudski čin koji se usklađuju i dopunjavaju).
Kada je osobu povrijedilo tuđe postupanje, a kako ne bi ostala zarobljena u prošlosti, može odabrati oproštenje, koje je posebice teško ako je riječ o njezinim roditeljima ili onima koji ne pokazuju kajanje za štetno postupanje. Osoba se odlučuje za opraštanje radi same sebe, svojeg duševnog zdravlja, svojih dobrih međuljudskih odnosa i time se odlučuje za dobar i smisleni život. Svaka osoba je odgovorna za vlastiti život, po slobodnoj volji će odlučiti što je za nju najsmisleniji odabir (Frankl, 1981: 106). Je li to ostati s osjećajima povrijeđenosti ili odabrati oproštenje s posljedično brojnim pozitivnim posljedicama.

Oprostiti nekome tko je pogrešno postupio, izuzetno je teško. Nerijetko je osobi potrebna pomoć koju joj može pružiti logoterapeut. Pahljina (2020) predlaže tzv. „Zamišljeni dijalog s udaljenim sugovornikom“. Odlučiti se za opraštanje znači usprkos svemu reći životu „da“. Ono što je ranjeno može se promijeniti, osoba se može odlučiti da promijeni stajalište prema sebi i situaciji te da povredu vidi kao nešto što joj je dao život, kao nešto što treba učiniti - oprostiti.

\section{ZAKLJUČAK}

Krivnja je svojstvena ljudima i povezana je s njihovom duhovnom slobodom, odgovornošću i savješću. Posljedica je pogrešnog izbora postupanja koje je u suprotnosti sa savješću. Savjest je ta koja 
pomaže $u$ odlučivanju između više mogućnosti i to na temelju spoznavanja „dobra i zla“, a bez te spoznaje ne bi bilo ni osjećaja krivnje.

Posljedice osjećaja krivnje nepovoljne su za zdravlje osobe te za njezine osobne i profesionalne odnose. Svatko ima tendenciju biti nepogrešiv, stoga priznavanje pogreške (štetno postupanje) predstavlja čin poniznosti. Prerastanje krivnje kroz traženje oproštenja čini osobu vrijednom življenja. S druge strane, oprostiti nekome zbog štetnog postupanja pokazuje da je osoba spremna prihvatiti činjenicu da joj život dao ne samo patnju nego i sposobnost izbora da zacijeli ranjeni dio sebe te slobodu da odabere stav da je, iako „ranjena“, sposobna oprostiti.

Svima je očito da nemamo mogućnost stvoriti svijet bez grubih riječi i grubih postupaka koji nekome predstavljaju izvor boli, gubitaka, konflikata, povrijeđenih osjećaja, ali isto tako svatko je za sebe slobodan odlučiti se za stvaranje svijeta mira i to nudeći i prihvaćajući oprost. Pritom odaberimo biti blagi prema sebi uz riječi Elisabeth Lukas (2021: 109): ,ljudska sloboda nije svemoguća, a ljudska spoznaja nije sveznajuća, pa u svojoj poniznosti moramo priznati da u svakom trenutku svog postojanja možemo djelovati maksimalno po 'najboljem znanju savjesti', što pak ne znači da iz naših dobrih namjera uvijek nastaju dobri učinci“.

\section{LITERATURA}

1. Frankl, V. E.. 1981. Nečujan vapaj za smislom. Zagreb. Naprijed.

2. Frankl, V. E. 2010. Čovjekovo traganje za smislom. Zagreb. Planetopija.

3. Hrvatska enciklopedija (2021). https://www.enciklopedija.hr/natuknica.asp $\mathrm{x}$ ?id=34057 (pristupljeno 12. siječnja 2021.).

\section{Jurković G. 2020. Kako se nositi s} osjećajem krivnje. https://book.hr/stvarnai-lazna-krivnja-kako-se-nositi-s-osjecajemkrivnje/ (pristupljeno 12. siječnja 2021.)

5. Lukas, E. 2000. Rendezvous mit dem Leben: Ermutigungen für die Zukunft. München. Kösel-Verlag.

6. Lukas, E. 2001. Duhovna psihologija: izvori smislena života. Đakovo. U pravi trenutak.

7. Lukas, E. 2013. Što nas u životu pokreće: Logoterapijski pristup. Zagreb. Biblioteka Oko tri ujutro.

8. Lukas, E. 2021. Konkretna logoterapija: Psihoterapija u dostojanstvu. Zagreb. Biblioteka Oko tri ujutro. 
9. Monbourquette, J. 1997. Kako oprostiti:

Oprostiti da se ozdravi. Ozdraviti da se

oprosti. Zagreb. Biblioteka Oko tri ujutro.

10. Monbourquette, J., d' Aspremont, I.

2014. Tražiti oproštenje, a ne poniziti se.

Zagreb. Biblioteka Oko tri ujutro.

11. Pahljina, C. 2020. Tragični trijas.

neobjavljeno predavanje (12. rujna 2020).

12. Penić, S., Čorkalo Biruški, D. 2008.

Predviđanje pripisivanja i prihvaćanja

kolektivne krivnje: uloga ratnoga

traumatskog iskustva. Društvena

istraživanja, 18/4-5, 851-874
13. Petz, B. (ur.). 1992. Psihologijski

rječnik. Zagreb. Prosvjeta.

14. Pilja, R. 2009. Razmatranje osjećaja

krivnje s teološke i psihološke perspektive.

KAIROS - Evanđeoski teološki časopis, 3/2, 365-375.

15. Smedes, L. B. 1997. Oprostiti $i$

zaboraviti: vidanje rana koje nismo

zavrijedili. Zagreb. Barka.

16. Tutu, D, Tutu, M. 2017. Knjiga

opraštanja. Četverostruki put iscjeljivanja

sebe i svijeta. Zagreb. NAR.

\section{SUMMARY \\ CULPABILITY AND FORGIVENESS}

Culpability from the aspect of the tragic triad of Victor Frankl's logotherapeutic approach is a life experience common to all people. Respecting the dignity of the person, culpability cannot be viewed in the exclusion of the freedom and responsibility of each individual person who chooses his or her behavior and for whom he or she cannot be acquitted. It can be said that there is almost no person who has not committed something that he could not forgive himself later, nor is there a person who has not experienced injustice. Whether a person is a "perpetrator" or a "victim", in order to reverse the many negative consequences of guilt, it is necessary to forgive, and the most difficult thing is to forgive yourself

The purpose of the paper is to encourage each person, especially those involved in helping professions, to reconsider the role of culpability in their lives and to think about the need for forgiveness as a prerequisite for personal and professional prosperity. The paper explains the constructs of culpability and forgiveness with special emphasis on the logotherapeutic approach.

Key words: culpability, forgiveness, logotherapy. 